\title{
Interface fracture energy of contact layers in a solid oxide cell stack
}

\author{
Han, Li; Talic, Belma; Kwok, Kawai; Hendriksen, Peter Vang; Frandsen, Henrik Lund
}

Published in:

Applied Energy Materials

Link to article, DOI:

10.1021/acsaem.9b02026

Publication date:

2020

Document Version

Peer reviewed version

Link back to DTU Orbit

Citation (APA):

Han, L., Talic, B., Kwok, K., Hendriksen, P. V., \& Frandsen, H. L. (2020). Interface fracture energy of contact layers in a solid oxide cell stack. Applied Energy Materials, 3(3), 2372-2385.

https://doi.org/10.1021/acsaem.9b02026

\section{General rights}

Copyright and moral rights for the publications made accessible in the public portal are retained by the authors and/or other copyright owners and it is a condition of accessing publications that users recognise and abide by the legal requirements associated with these rights.

- Users may download and print one copy of any publication from the public portal for the purpose of private study or research.

- You may not further distribute the material or use it for any profit-making activity or commercial gain

- You may freely distribute the URL identifying the publication in the public portal

If you believe that this document breaches copyright please contact us providing details, and we will remove access to the work immediately and investigate your claim 


\title{
Acs APPLIED ENERGY MATERIAI
}

\section{Article}

\section{Interface fracture energy of contact layers in a solid oxide cell stack}

\author{
Li Han, Belma Talic, Kawai Kwok, Peter Vang Hendriksen, and Henrik Lund Frandsen
}

ACS Appl. Energy Mater., Just Accepted Manuscript • DOI: 10.1021/acsaem.9b02026 • Publication Date (Web): 31 Jan 2020

Downloaded from pubs.acs.org on February 3, 2020

\section{Just Accepted}

"Just Accepted" manuscripts have been peer-reviewed and accepted for publication. They are posted online prior to technical editing, formatting for publication and author proofing. The American Chemical Society provides "Just Accepted" as a service to the research community to expedite the dissemination of scientific material as soon as possible after acceptance. "Just Accepted" manuscripts appear in full in PDF format accompanied by an HTML abstract. "Just Accepted" manuscripts have been fully peer reviewed, but should not be considered the official version of record. They are citable by the Digital Object Identifier (DOI®). "Just Accepted" is an optional service offered to authors. Therefore, the "Just Accepted" Web site may not include all articles that will be published in the journal. After a manuscript is technically edited and formatted, it will be removed from the "Just Accepted" Web site and published as an ASAP article. Note that technical editing may introduce minor changes to the manuscript text and/or graphics which could affect content, and all legal disclaimers and ethical guidelines that apply to the journal pertain. ACS cannot be held responsible for errors or consequences arising from the use of information contained in these "Just Accepted" manuscripts. 


\title{
Interface Fracture Energy of Contact Layers in a Solid Oxide Cell Stack
}

\author{
Li Han a , Belma Talic ${ }^{a}$, Kawai Kwok ${ }^{\mathrm{a}, \mathrm{b}}$, Peter Vang Hendriksen ${ }^{\mathrm{a}}$, and Henrik Lund Frandsen ${ }^{\mathrm{a}}$ \\ a Department of Energy Conversion and Storage, Fysikvej Building 310, Technical University of Denmark, 2800 Kgs. \\ Lyngby, Denmark \\ ${ }^{b}$ Department of Mechanical and Aerospace Engineering, University of Central Florida, Orlando, Florida 32816, USA
}

\begin{abstract}
A critical factor for improving the long-term stability/reliability of solid oxide cell stacks is ensuring good adhesion between the stack components. Specifically, ensuring strong adherence between the oxygen electrode and the interconnect is challenging. This work compares the suitability of several materials as contact layers between a $\mathrm{La}_{0.6} \mathrm{Sr}_{0.4} \mathrm{CoO}_{3-8}-\mathrm{Ce}_{0.8} \mathrm{Gd}_{0.2} \mathrm{O}_{2}$ composite oxygen electrode and $\mathrm{Mn}_{1.5} \mathrm{Co}_{1.5} \mathrm{O}_{4}$ or Co coated metallic interconnects. The contact materials were screened based on measurements of the interface fracture energy using four-point bending of sandwiched samples. The highest fracture energies were measured using a CuMn metallic, spinel forming foam as the contact layer. The fracture energy of the interface between a $\mathrm{Mn}_{1.5} \mathrm{Co}_{1.5} \mathrm{O}_{4}$ coated interconnect and the contact layer is $\sim 8$ times higher using the CuMn foam compared to using conventional $\left(\mathrm{La}_{0.8} \mathrm{Sr}_{0.2}\right)_{0.98} \mathrm{MnO}_{3-\sigma}, \mathrm{La}_{0.6} \mathrm{Sr}_{0.4} \mathrm{CoO}_{3-\delta},\left(\mathrm{La}_{0.8} \mathrm{Sr}_{0.2}\right)_{0.98} \mathrm{MnO}_{3-\sigma}+\mathrm{La}_{0.6} \mathrm{Sr}_{0.4} \mathrm{CoO}_{3-\delta}$ or $\mathrm{LaNi}_{0.6} \mathrm{Fe}_{0.4} \mathrm{O}_{3}$ as the contact material. The interface bonding and fracture mechanisms are discussed on the basis of scanning electron microscopy investigations.
\end{abstract}

Key words: solid oxide electrolysis cell; solid oxide fuel cell; contact layer; interface adhesion; fracture energy; contact; integrity

\section{Introduction}

A solid oxide electrolysis cell (SOEC) can be used to convert $\mathrm{CO}_{2}$ and/or steam into $\mathrm{CO}$ and $\mathrm{H}_{2}$, which after catalytic upgrade to e.g. methane or methanol can be conveniently stored. The same cell can be used in the reverse mode (SOFC) to convert these fuels back to electricity. The overall energy efficiency of this process is one of the highest among competing technologies, making SOFC/SOEC a promising technology for smart grid concepts, where excess electric power on the grid can be converted to fuels for the transport sector or stored and converted back to electricity when the demand exceeds production [1-4].

In order to attain a higher power density or production capacity, multiple solid oxide cells (SOC) are combined into a stack. Stacking can be realized based on a number of different cell architectures; e.g. tubular [5], microtubular [6], segmented cells in series [7,8], or planar cells; each design having their specific merits and engineering challenges. In the planar design, the cells are connected in series by use of metallic interconnect plates and glasses/glass-ceramics are used for sealing $[9,10]$. This design is advantageous in terms of the achievable powder density, but due to the limiting firing/assembly temperature set by the interconnect and seal, ensuring strong adherence between the stack components is challenging. Especially, the interface between the interconnect and the oxygen electrode of the cell is weak and prone to loss of contact [11-13]. Delamination at this interface is critical as it may lead to hot-spots and consequently accelerated corrosion and degradation in the SOC stack [14$16]$.

Ceramic contact layers are often used between the interconnect and the oxygen electrode in planar stacks in order to improve the mechanical bonding and electrical contact, as illustrated in Fig. 1. The contact layer should be

\footnotetext{
* Corresponding author: hlfr@dtu.dk
} 
stable in an oxidizing atmosphere and chemically compatible with both the oxygen electrode and the interconnect and its coating materials. Contact materials are usually chosen on the basis of their electrical conductivity and coefficient of thermal expansion (CTE). Perovskite-type oxides such as $\mathrm{La}_{0.6} \mathrm{Sr}_{0.4} \mathrm{CoO}_{3-\delta}$ (LSC) [17], $\left(\mathrm{La}_{0.8} \mathrm{Sr}_{0.2}\right)_{0.98} \mathrm{MnO}_{3-\sigma}(\mathrm{LSM})$ [18], and $\mathrm{LaNi}_{0.6} \mathrm{Fe}_{0.4} \mathrm{O}_{3}$ (LNF) [19] are "popular" choices. LSC has a high specific conductivity, up to $1700 \mathrm{~S} / \mathrm{cm}$ at $800^{\circ} \mathrm{C}$ [20]. However, it's average CTE of $17.5 \mathrm{ppm} \mathrm{K}{ }^{-1}\left(\mathrm{RT}-800^{\circ} \mathrm{C}\right)$ is relatively high compared to that of other typically used stack components such as Yttria Stabilized Zirconia (YSZ), which has a CTE of $10.5 \mathrm{ppm} \mathrm{K}^{-1}\left(\mathrm{RT}-800^{\circ} \mathrm{C}\right)$ [21]. The CTEs of LSM $\left(12.0 \mathrm{ppm} \mathrm{K}^{-1}, 30-800^{\circ} \mathrm{C}\right.$ [21]) and LNF $(11.8$ ppm K $\left.{ }^{-1}, \mathrm{RT}-800^{\circ} \mathrm{C}[19]\right)$ are more suitable, while their electrical conductivities are slightly lower (300-600 S/cm at $800{ }^{\circ} \mathrm{C}$ ) [22,23]. If the interconnect coating does not serve as a sufficient barrier against $\mathrm{Cr}$ diffusion and evaporation, Sr-doped perovskites such as LSC and LSM may form poorly conductive $\mathrm{SrCrO}_{4}$ and $/ \mathrm{or} \mathrm{Sr}_{3} \mathrm{Cr}_{2} \mathrm{O}_{8}$ phases, thus leading to an increased interface resistance with time [24]. In this respect Sr-free LNF is an attractive material [19].

Recently, the use of metallic CuMn or CuNi alloy foam as a new type of contact layer was suggested [25-27]. The flexibility of these foams in the metallic state allows for greater manufacturing tolerances, while the highly porous structure is ideal for gas permeation. During heat-up of the stack, the metallic foams are converted to conductive spinel oxides such as $\mathrm{Cu}_{1+\mathrm{x}} \mathrm{Mn}_{2-\mathrm{x}} \mathrm{O}_{4}\left(\sim 200 \mathrm{~S} / \mathrm{cm}^{2}\right.$ at $\left.750{ }^{\circ} \mathrm{C}\right)$ in case of the CuMn foam [28].

Since one of the main functions of the contact layer is to ensure a stable electrical contact between the interconnect and oxygen electrode, different contact layers are typically evaluated based on measurements of the area specific resistance (ASR) [24,29]. The ASR is a function of the contact area between the cell and the interconnect and can therefore serve as an indication of the interface bonding [30]. However, as the electrical conductivity can be influenced by interdiffusion or reaction between the different layers, it is in addition important to evaluate the interface adhesion though more direct methods. Lu et al. [31] used an axial pulling tests to evaluate the contact bonding strength of a NiCo-based contact, but reported that this method was unsuccessful for measuring the bonding strength of a LSCF-based contact, due to a relatively weaker bonding. Boccaccini et al. [32] investigated the bonding strength and bonding mechanisms of the SOFC IC/electrode interface using a three point bending test based on the ISO 9693 standard. The disadvantage of this method is, however, that the maximum stress at crack initiation, which is the measured quantity, depends on the local geometry at the assembly point.

Another way to evaluate the mechanical adhesion at interfaces is on the basis of the critical fracture energy release rate $(G)$, which defines the energy dissipated per unit area during the fracture. This quantity is preferable compared to the interface fracture strength, as $\mathrm{G}$ is independent of the specific interface geometry, in particular at the crack initiation point. Charalambides et al. [33] originally proposed a four-point bending test to determine the critical energy release rate at metal-ceramic interfaces, which was later improved by Hofinger et al. [34] to enable an evaluation of the interface fracture toughness of thin, brittle layers. The main advantage of this method is that the crack growth is stable during constant displacement rate of the actuator, allowing for the acquirement of many fracture energy measurements on each sample. Furthermore, the influence of residual stresses can be neglected if a symmetrical sample is tested. This methodology has previously been used by Tucker et al. [35] for measuring the interface mechanical adhesion of LSM-based contact layers. It has also been used to measure the fracture energy of glass sealing assemblies for SOFC stacks [36,37].

Ensuring reliability of the cell to interconnect interface is one of the most important issues with the planar stack architecture and thus of great importance to address in research and development, both in engineering solutions, but also in developing consistent characterization methods. In this study, we have systematically tested and analyzed the fracture energy of the interfaces between different contact layers, oxygen electrodes and coated interconnects. The tested materials cover the common perovskite-oxide contact layer materials LSC, LSM, LSCLSM, LNF, as well as the more novel spinel forming CuMn metallic foam. $\mathrm{La}_{0.6} \mathrm{Sr}_{0.4} \mathrm{CoO}_{3-\delta}-\mathrm{Ce}_{0.8} \mathrm{Gd}_{0.2} \mathrm{O}_{2}$ (LSC$\mathrm{CGO}$ ) is chosen as the oxygen electrode and $\mathrm{Mn}_{1.5} \mathrm{Co}_{1.5} \mathrm{O}_{4}(\mathrm{MCO})$ or Co coated Crofer $22 \mathrm{APU}$ as the interconnect. The bonding mechanism and fracture behavior is discussed based on post-fracture analysis. 


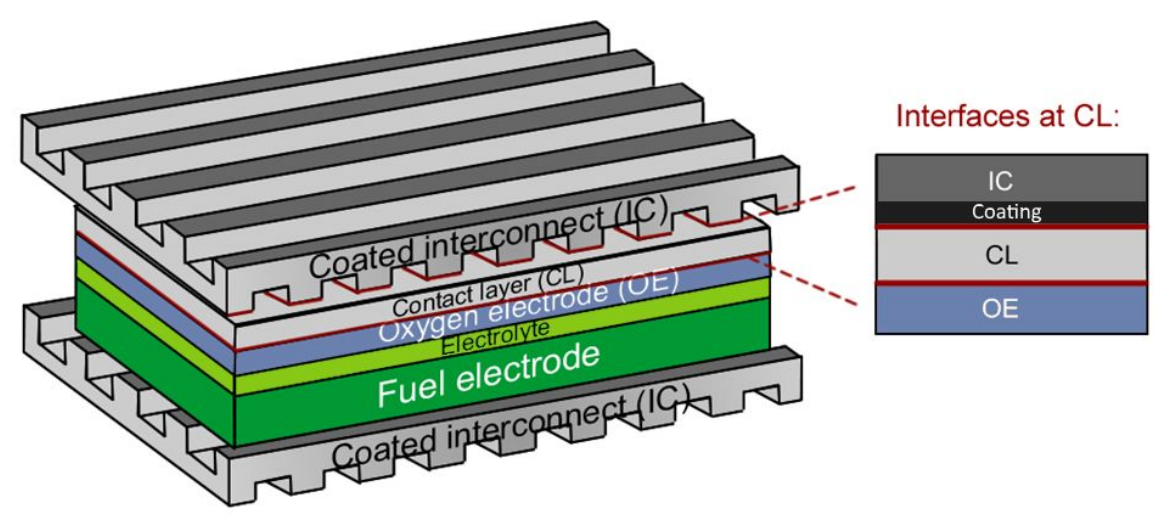

Fig. 1 Schematics of a single repeating unit in a planar SOEC stack. The interfaces with the contact layer are outlined with red color.

\section{Experimental}

Samples were fabricated using the notched three-layer-sandwich structure originally proposed by Hofinger et al. [34], illustrated in Figure 2. Crofer 22 APU (VDM Materials) ferritic stainless steel in $0.3 \mathrm{~mm}$ thickness was used as the substrate in all cases. The steel was coated with either $\mathrm{Mn}_{1.5} \mathrm{Co}_{1.5} \mathrm{O}_{4}(\mathrm{MCO})$ by electrophoretic deposition (EPD), or metallic Co by electroplating. Details on the coating processes can be found elsewhere [38,39]. The MCO coated steel was heat treated at $900{ }^{\circ} \mathrm{C}$ in air for $2 \mathrm{~h}$ to sinter the coating, while the Co coated steel was used in the as-prepared state.

Using the coated steel substrates, sandwiches of four different layer sequences were prepared: 1) MCO or Co coated substrates with a screen printed perovskite oxide contact layer (CL), 2) MCO or Co coated substrates with a CuMn foam CL, 3) MCO coated substrates with screen printed oxygen electrode (OE) and CL, and 4) MCO coated substrates with a screen printed $\mathrm{OE}$ layer and $\mathrm{CuMn}$ foam $\mathrm{CL}$. The different configurations are schematically illustrated in Figure 2b. Sample type 1 and 2 were used for determining the fracture energy of the contact layer/interconnect interface, while sample types 3 and 4 were used for determining the fracture energy of the contact layer/oxygen electrode interface.

For sample type 1), 4 different CL materials, $\mathrm{La}_{0.6} \mathrm{Sr}_{0.4} \mathrm{CoO}_{3-\delta}$ (LSC), $\left(\mathrm{La}_{0.8} \mathrm{Sr}_{0.2}\right)_{0.98} \mathrm{MnO}_{3-\delta}$ (LSM), LSC-LSM, and $\mathrm{LaNi}_{0.6} \mathrm{Fe}_{0.4} \mathrm{O}_{3}$ (LNF), were screen printed on the $\mathrm{MCO}$ or Co coated steel. The printed layers were dried at $110{ }^{\circ} \mathrm{C}$ for $30 \mathrm{~min}$, after which the samples were laser cut into $3 \times 30 \mathrm{~mm}^{2}$ pieces, to serve as the upper substrates. Coated steel laser cut into $3 \times 60 \mathrm{~mm}^{2}$ pieces served as the lower substrate.

For sample type 2), CuMn foam (Alantum Corporation, Korea) was cut to $3 \times 60 \mathrm{~mm}^{2}$ and sandwiched between MCO or Co coated steel substrates laser cut into $3 \times 30 \mathrm{~mm}^{2}$ and $3 \times 60 \mathrm{~mm}^{2}$ pieces. The CuMn foam had a Cu:Mn ratio of 3:2, $700 \mu \mathrm{m}$ initial thickness, $87 \%$ initial porosity and $\sim 450 \mu \mathrm{m}$ pore size. Before use, the foam was coldrolled to reduce the thickness to $250-300 \mu \mathrm{m}$.

For sample type 3), MCO coated steel was screen printed with a CL (LSC, LSM, LSC-LSM or LNF), dried at $110^{\circ} \mathrm{C}$ for $30 \mathrm{~min}$ and further screen printed with an LSC-CGO oxygen electrode layer. The samples were annealed at $900{ }^{\circ} \mathrm{C}$ for $1 \mathrm{~h}$ to sinter the oxygen electrode and subsequently laser cut into $3 \times 30 \mathrm{~mm}^{2}$ pieces to serve as the upper substrates. The relatively mild sintering conditions for the oxygen electrode were chosen in order to avoid excessive corrosion of the steel substrate. The lower substrate consisted of MCO coated steel screen printed with a CL (LSC, LSM, LSC-LSM or LNF), dried at $110^{\circ} \mathrm{C}$ for $30 \mathrm{~min}$, and laser cut into $3 \times 60 \mathrm{~mm}^{2}$ pieces. 
For sample type 4), MCO coated steel was screen printed with a LSC-CGO oxygen electrode layer, annealed at $900{ }^{\circ} \mathrm{C}$ for 1 and laser cut into $3 \times 30 \mathrm{~mm}^{2}$ and $3 \times 60 \mathrm{~mm}^{2}$ pieces. The CuMn foam was cut to $3 \times 60 \mathrm{~mm}^{2}$ and sandwiched between the steel substrates as shown in Figure $2 \mathrm{~b}$.

The upper and lower substrates of all three sample types were assembled as illustrated in Fig. 2a and hot pressed in a furnace at $900{ }^{\circ} \mathrm{C}$ for $10 \mathrm{~h}$ with a uniaxial load of $28 \mathrm{~N} / \mathrm{cm}^{2}$. These assembly conditions were chosen to represent those applied during stack assembly when using a glass-ceramic sealant [36]. The different material combinations and layering sequences total to 14 different combinations, summarized in Table 1 . For each of the 14 combinations, two samples were tested. One additional sample of each type was assembled for microscopy analysis before fracture.

The bonded sandwich structure after hot pressing is illustrated in Fig. 2c. The thickness of the upper substrate, middle ceramic layer, and lower substrate is labeled as $h_{1}, h_{2}$, and $h_{3}$, respectively. Four-point bending tests were carried out using an in-house built mechanical testing apparatus [40]. In this, the two inner rolls are moved towards the two outer rolls with a constant displacement rate $(0.01 \mathrm{~mm} / \mathrm{s})$ loading the sample. The load $(P)$ on the two outer rolls are recorded by two load cells during the measurement [40], see the schematics in Fig. 2 d. A more detailed description of the test methodology and analysis is presented in Section 3.

A scanning electron microscope (SEM, Supra; Carl Zeiss, Inc.) was used in combination with energy dispersive $\mathrm{X}$-ray spectroscopy (EDS) to characterize the microstructures of the samples after assembly at $900{ }^{\circ} \mathrm{C}$ and after the four-point bending test. For cross sectional inspections the samples were cold-vacuum embedded in epoxy and polished with SiC-paper and diamonds in suspension down to $1 \mu \mathrm{m}$.

\section{Table 1}

Summary of the tested interfaces. OE $=$ LSC-CGO oxygen electrode, IC $=$ Crofer 22 APU interconnect

\begin{tabular}{ccccc}
\hline $\begin{array}{c}\text { Contact layer } \\
(\mathbf{C L})\end{array}$ & $\begin{array}{c}\text { Sample } \\
\#\end{array}$ & Upper sub. & Interface & Lower sub. \\
\hline \multirow{2}{*}{ LSC } & 1 & IC-MCO + LSC & $/$ & IC-MCO \\
& 2 & IC-Co + LSC & $/$ & IC-Co \\
& 3 & IC-MCO + LSC + OE & $/$ & LSC + IC-MCO \\
\hline \multirow{2}{*}{ LSM } & 4 & IC-MCO + LSM & $/$ & IC-MCO \\
& 5 & IC-Co + LSM & $/$ & IC-Co \\
\hline \multirow{2}{*}{ LSC+LSM } & 6 & IC-MCO + LSM + OE & LSM + IC-MCO \\
\hline \multirow{2}{*}{ LNF } & 7 & IC-MCO + LSCLSM & $/$ & IC-MCO \\
& 10 & IC-MCO + LSCLSM + OE & LSCLSM + IC-MCO \\
\hline \multirow{2}{*}{ CuMn foam } & 11 & IC-MCO + LNF & IC-Co + LNF & IC-MCO \\
& 12 & IC-MCO + LNF + OE & CuMn foam & IC-Co \\
& 14 & IC-MCO & CuMn foam & IC-MCO \\
\hline
\end{tabular}


(a)

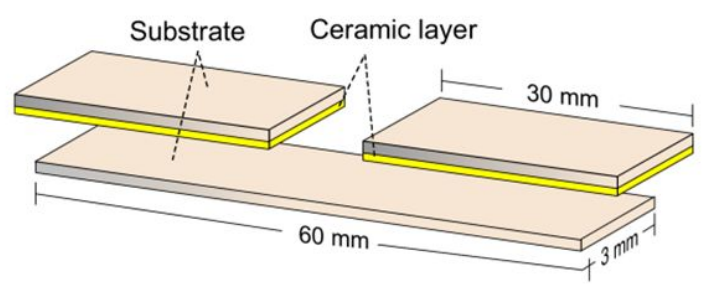

(b)

4 types of layer sequences:
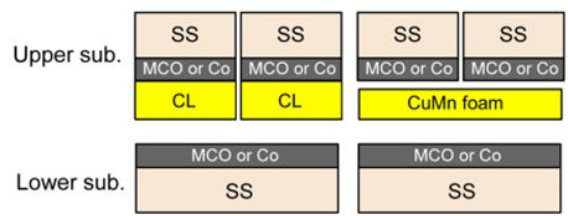

\begin{tabular}{|c|c|}
\hline$S S$ & $S S$ \\
\hline$M C O$ & $M C O$ \\
\hline$C L$ & $C L$ \\
\hline$O E$ & $O E$ \\
\hline
\end{tabular}

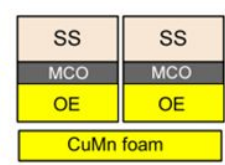

(c)

(d)
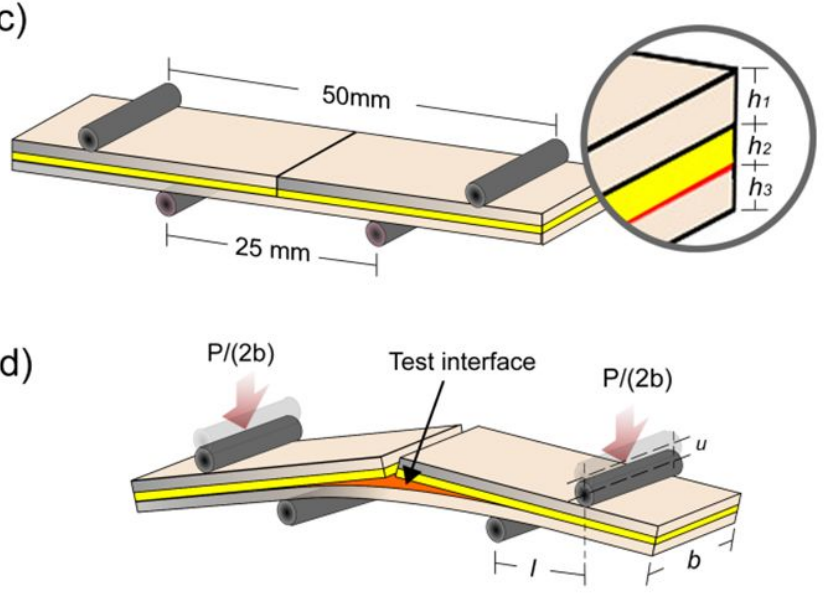

(e)

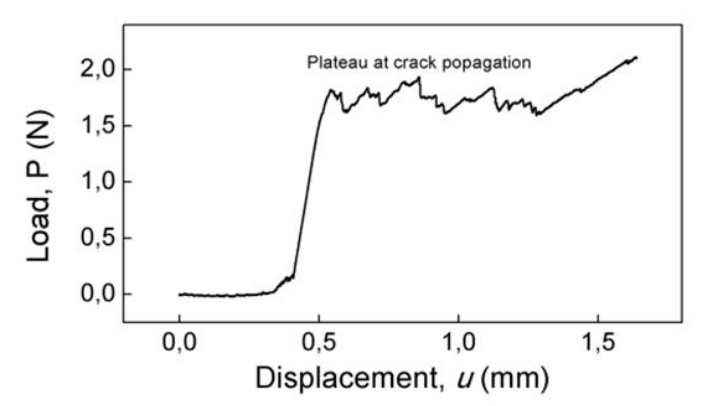

Fig. 2 Schematics of (a) sample components and geometry before bonding, (b) The different layer sequences of the tested samples, $\mathrm{SS}=$ stainless steel, $\mathrm{CL}=$ contact layer, $\mathrm{OE}=$ oxygen electrode. (c) Positions of the four point bending pins and dimensions of the test sample after bonding, in which $h_{1}, h_{2}$, and $h_{3}$ are the thickness of the upper steel substrate, the ceramic layer(s), and the lower steel substrate, respectively. (d) Illustration of the symmetric cracking at the interface during the fourpoint bending test. The upper pins are displaced by $u$ along the vertical direction of the load, $P$. $l$ is the difference of outer to inner span, and $b$ is the sample width. (e) Example of the load vs. displacement curve recorded during the four-point bending test. 


\section{Analysis}

\subsection{Fracture energy determination}

Under the loading condition, a constant bending moment $M_{\mathrm{b}}$ exists along the sample cross section.

$$
M_{b}=\frac{P l}{2 b}
$$

where $P$ denotes the applied force, $l / 2$ is half the difference of outer to inner span, and $b$ is the sample width (see Fig. 2c). In the applied setup, $l$ is $1.25 \times 10^{-3} \mathrm{~m}$ and $b$ is $3 \times 10^{-3} \mathrm{~m}$. The applied force reaches a steady-state value when the crack propagates, for which the fracture energy release rate $(G)$ can be calculated [41]. Under the assumption of Hooke's law, the steady-state fracture energy was calculated using Hofinger's modification of Charalambides' equations [34]:

$$
G=\frac{M_{b}^{2}\left(1-v_{3}^{2}\right)}{2 E_{3}}\left(\frac{1}{I_{3}}-\frac{1}{I_{c}}\right)
$$

where $I_{3}$ is the second moment of area for the lower substrate and $I_{\mathrm{c}}$ is the second moment of area for the combination of all the layers. $I_{3}$ and $I_{\mathrm{c}}$ are calculated as follows [34]:

$$
I_{3}=\frac{h_{3}^{3}}{12}
$$

and

$$
I_{c}=\frac{h_{3}^{3}}{3}+\kappa \frac{h_{2}^{3}}{3}+\mu\left(\frac{h_{1}^{3}}{3}+h_{1}^{3} h_{2}+h_{2}^{2} h_{1}\right)-\frac{\left[h_{3}^{2}-\kappa h_{2}^{2}-\mu\left(h_{1}^{2}+2 h_{2} h_{1}\right)\right]^{2}}{4\left(h_{3}+\kappa h_{2}+\mu h_{1}\right)}
$$

with

$$
\kappa=\frac{E_{2}\left(1-v_{3}^{2}\right)}{E_{3}\left(1-v_{2}^{2}\right)}, \quad \mu=\frac{E_{1}\left(1-v_{3}^{2}\right)}{E_{3}\left(1-v_{1}^{2}\right)}
$$

where $h$ is layer thickness, $E$ is Young's modulus, and $v$ is Poisson's ratio. The subscripts 1 , 2, and 3 refer to the upper steel substrate, the contact layer, and the lower steel substrate, respectively. The material parameters and measured layer thicknesses used in the calculations can be found in Table 2 .

Table 2

Material parameters used for the Charalambides equations

\begin{tabular}{ccccc}
\hline Components & $v$ & $E(G P a)$ & $h\left(10^{-3} \mathrm{~m}\right)$ & Reference \\
\hline IC-MCO & 0.3 & 220 & 0.34 & {$[42]$} \\
IC-Co & 0.3 & 220 & 0.32 & {$[42]$} \\
OE & 0.3 & 10 & 0.025 & {$[43]$} \\
LSC & 0.3 & 80 & 0.035 & {$[43]$, modified } \\
LSM & 0.3 & 80 & 0.025 & {$[43]$, modified } \\
\hline
\end{tabular}




\begin{tabular}{ccccc} 
LSC+LSM & 0.3 & 80 & 0.04 & {$[43]$, modified } \\
LNF & 0.3 & 80 & 0.02 & {$[43]$, modified } \\
$\begin{array}{c}\text { CuMn foam } \\
\text { (Oxidized) }\end{array}$ & 0.3 & 4.5 & 0.23 & tested in this work \\
\hline
\end{tabular}

During the four-point bending test the applied load and measured displacement are recorded. An example of the data is shown in Fig 2e. The load increases linearly with the displacement until the critical load for crack propagation is reached. As the crack propagates, the load drops due to the reduced stiffness of the cracked sandwiched specimen. Since the load is now below the critical value, the crack propagation comes to a momentary halt. As the vertical displacement is further increased, the load increases until it again reaches the critical value for crack propagation. This process repeats resulting in a slightly fluctuating load level until the crack reaches the inner rolls.

In the "constant load" regime the load fluctuates due to variations in the crack interface. However, the forcedisplacement curve overall displays a plateau of crack propagation from which the interface toughness $\left(G_{c}\right)$ can be deduced. The fracture energy release rate $(G)$ was calculated using the average of the load $(P)$ along the plateau according equations 1 and 2 . The standard deviation was deduced from the observed scatter around this average value.

\subsection{Thermal expansion coefficient mismatch and residual stresses}

The test sandwiches were bonded at high temperature and cooled down to room temperature for the mechanical test. This gives rise to build up of residual stresses due to the thermal expansion coefficient (CTE) mismatch between the layers. Some of the materials have relatively high CTE mismatch to that of the interconnect steel, which is the structurally dominating component. For example $\mathrm{La}_{0.6} \mathrm{Sr}_{0.4} \mathrm{CoO}_{3-\delta}$ (LSC) has an average CTE of 17.5 ppm K $\mathrm{K}^{-1}$ in the range from RT to $800^{\circ} \mathrm{C}$ [22], which is much higher than the CTE of the Crofer 22 APU substrate (11.9 $\mathrm{ppm} \mathrm{K}^{-1}$ between $20-800^{\circ} \mathrm{C}$ [42]) and the MCO coating (10.8-14.4 $\mathrm{ppm} \mathrm{K}^{-1}$ depending on the $\mathrm{Mn} / \mathrm{Co}$ ratio $[44,45])$. However, due to the symmetrical character of the samples applied here the estimated fracture energy $(G)$ is practically unaffected by the state of the residual stresses as these hardly change upon delamination. Because the two symmetrically located, stiffer structural members (i.e. the steel) have the same CTE, the only dimensional change (release of residual stress) after failure is due to that the ceramic layer may only attach to one substrate. Since the contact layers are much softer than the steel the overall dimension will not change. The energy release due to the residual stress release was estimated to be in the order of $0.06 \mathrm{~J} / \mathrm{m}^{2}$ for the chosen materials and layer thicknesses, and thus not influencing the results significantly.

\section{Results}

\subsection{Fracture Energy measurements}

The measured fracture energies are plotted in Fig. 3. All of the conventional ceramic contact layers (LSC, LSM, LSC+LSM and LNF) have fracture energies in the order of $1 \mathrm{~J} / \mathrm{m}^{2}$ after the applied heat treatment $\left(10 \mathrm{~h}\right.$ at $900{ }^{\circ} \mathrm{C}$ and $28 \mathrm{~N} / \mathrm{cm}^{2}$ ). With CuMn foam as the contacting layer the fracture energy of the CL/OE and CL/IC-Co interfaces is doubled compared to the average fracture energy achieved with the perovskite oxide contact layers. Moreover, for the CL/IC-MCO interface the fracture energy is eight times larger than the average fracture energy achieved with the perovskite oxide contact layers. 


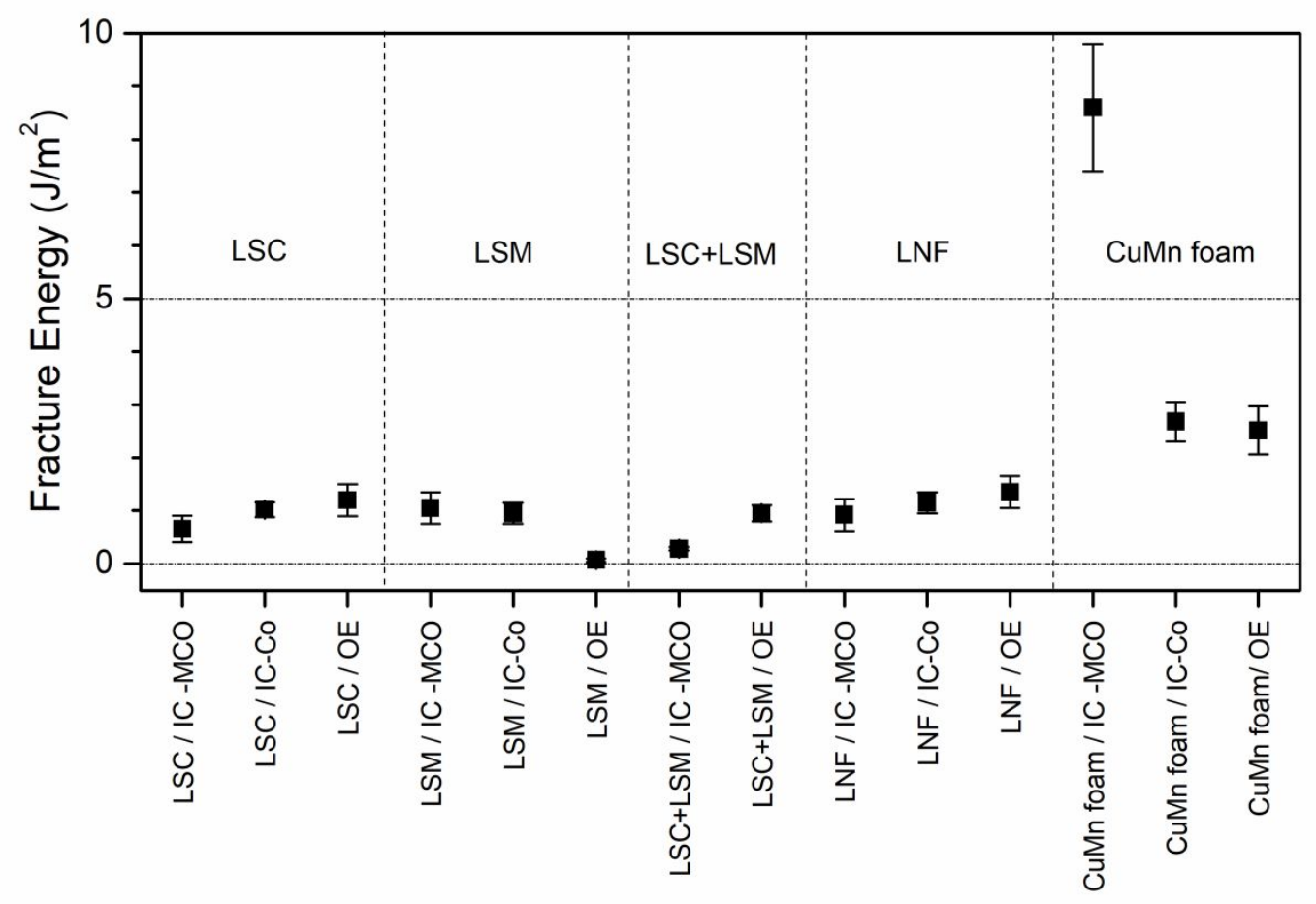

Fig. 3 Interface fracture energy for the various contact layer(CL)/interconnect(IC) and contact layer(CL)/oxygen electrode(OE) interfaces.

\subsection{Post-test analysis}

The tested samples were inspected by SEM and EDS in order to elucidate the differences in the fracture energy. The sandwiches were manually taken apart after the four-point bend test to inspect the fracture surface. In addition, the cross sections of equivalent, but non-fractured samples were inspected after the assembly at $900{ }^{\circ} \mathrm{C}$.

\subsubsection{LSC interfaces}

SEM images and EDS analysis of samples with a LSC contact layer are shown in Figure 4. In case of the LSC/ICMCO interface, the morphology of the fracture surface (Fig. 4b) indicates that the majority of the delamination has taken place along the interface between the LSC contact layer and the MCO coating and that the LSC in certain areas has been pulled off along with the MCO coating. The overall fracture pattern, illustrated in the insert of Fig. $4 \mathrm{~b}$, indicates a non-homogeneous bonding between the two layers, possibly due to surface irregularities that could not be alleviated during the hot press assembly $\left(10 \mathrm{~h}\right.$ at $\left.900{ }^{\circ} \mathrm{C}, 28 \mathrm{~N} / \mathrm{cm}^{2}\right)$. Cross sectional analysis of the equivalent sample right after assembly shows a $\sim 3 \mu \mathrm{m}$ thick interdiffusion zone at the LSC/MCO interface (Fig 4a). Comparing the elemental profiles for $\mathrm{La}$ and $\mathrm{Sr}$ indicates that $\mathrm{Sr}$ is the more mobile element. The interdiffusion of elements creates a chemical bonding between LSC and the MCO coating, but this bonding is clearly limited to only a few points (cf. Fig $4 \mathrm{~b}$ ), likely due to surface irregularities. 
A similar fracture pattern is observed in case of the LSC/IC-Co interface (Fig. 4d). The cross section of the interface after assembly (Fig. 4c) shows that the originally metallic Co coating has been oxidized to $\mathrm{Co}_{3} \mathrm{O}_{4}$ after the high temperature assembly in air, and that a $\mathrm{Cr}_{2} \mathrm{O}_{3}$ scale is formed between the steel and the coating. Particles of LSC appear to be integrated in the surface of the $\mathrm{Co}_{3} \mathrm{O}_{4}$ coating, resulting in a mechanical interlocking. This interlocking is likely because the load during assembly is applied before the coating is oxidized, allowing for some LSC particles from the contact layer to be pressed into the softer Co metal layer. Upon heating in air, the volume expansion from the oxidation of the Co coating leads to incorporation of the LSC particles. As a result, the fracture energy of the LSC/IC-Co interface $\left(1.0 \pm 0.1 \mathrm{~J} / \mathrm{m}^{2}\right)$ is slightly higher than that of the LSC/IC-MCO interface $\left(0.7 \pm 0.3 \mathrm{~J} / \mathrm{m}^{2}\right)$.

The strongest interface for samples with the LSC contact layer is that between the contact layer and the LSC-CGO oxygen electrode $\left(1.2 \pm 0.3 \mathrm{~J} / \mathrm{m}^{2}\right)$. The fracture surface (Fig. $\left.4 \mathrm{f}\right)$ indicates that the delamination has taken place at the CL/OE interface as well as along the CL/MCO interface. The cross section of the LSC/LSC-CGO interface after assembly (Fig. 4e) shows an intimate interface with mild mechanical interlocking of the two layers. The similar composition of the two layers makes it difficult to evaluate the extent of interdiffusion along the interface. Nevertheless, given the common LSC material in the contact layer and oxygen electrode it is likely that the bonding has been realized by a very mild sintering between the two layers during the assembly at $900{ }^{\circ} \mathrm{C}$ and $28 \mathrm{~N} / \mathrm{cm}^{2}$. 

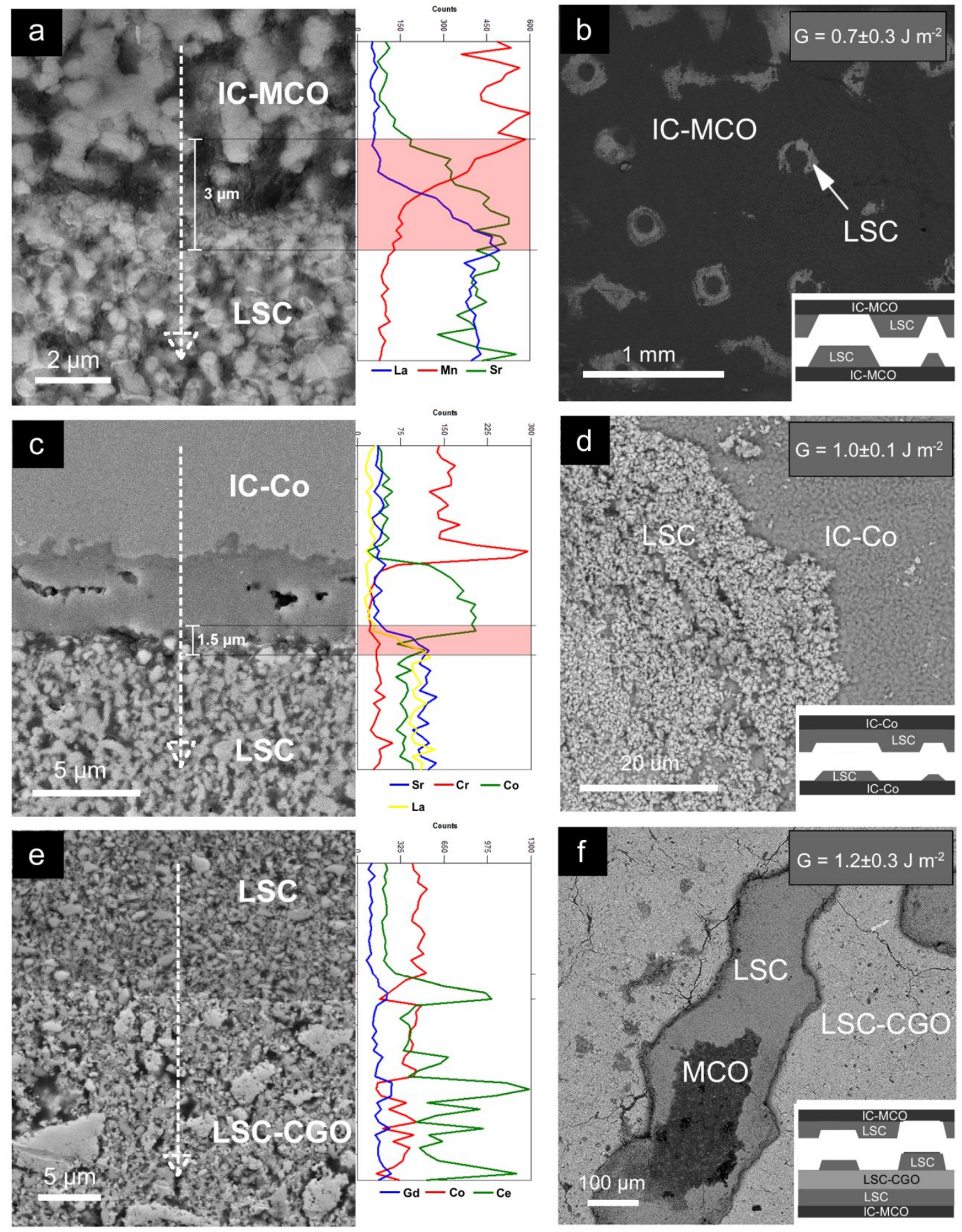

Fig. 4 SEM images and EDS spectrums of contact interfaces for (a) LSC/IC-MCO before fracture, (b) LSC/ IC-MCO after fracture, (c) LSC/IC-Co before fracture, (d) LSC/ IC-Co after fracture, (e) LSC/OE before fracture, (f) LSC/OE after fracture. The highlighted region in EDS spectrums in (a), (c), and (e) are interfacial transition zones. 


\subsubsection{LSM interfaces}

The LSM contact layer resulted in a comparable fracture energy for the LSM/IC-MCO $\left(1.1 \pm 0.3 \mathrm{~J} / \mathrm{m}^{2}\right)$ and LSM/ICCo $\left(1.0 \pm 0.2 \mathrm{~J} / \mathrm{m}^{2}\right)$ interfaces. An EDS linescan across the LSM/IC-MCO interface after assembly (Fig. 5a) shows a $2 \mu \mathrm{m}$ thick interdiffusion zone containing $\mathrm{La}, \mathrm{Sr}$ and $\mathrm{Co}$. Here, $\mathrm{La}$ and $\mathrm{Sr}$ have diffused nearly equal distance into the MCO coating, which is in contrast to the finding with the LSC contact layer, where Sr diffusion dominated (cf. Fig. 4a). The fractured surface of the LSM/IC-MCO sample (Fig. 5b) shows residual LSM particles on the ICMCO surface, indicating the fracture process schematically illustrated in the figure inset (i.e. the main fracture is along the LSM/MCO interface).

Fig. 5c shows the SEM-EDS line scan of the LSM/IC-Co interface after assembly. The Co coating has oxidized to a $\mathrm{Co}_{3} \mathrm{O}_{4}$ coating and a $\sim 2 \mu \mathrm{m}$ thick $\mathrm{Cr}_{2} \mathrm{O}_{3}$ scale is formed between this coating and the Crofer 22 APU substrate. Also here some of the LSM particles from the contact layer have become incorporated into the $\mathrm{Co}_{3} \mathrm{O}_{4}$, likely as a result of the applied pressure and oxidation of the Co-coating. The LSM particles are found deeper below the $\mathrm{Co}_{3} \mathrm{O}_{4}$ surface relative to the LSC particles (cf. Fig 4c), which is likely due to the larger particle size of the former. The SEM image of the fracture surface in Fig. $5 \mathrm{~d}$ shows that the fracture occurred both at the $\mathrm{LSM} / \mathrm{Co}_{3} \mathrm{O}_{4}$ interface and within the $\mathrm{LSM}$, i.e. the $\mathrm{LSM} / \mathrm{Co}_{3} \mathrm{O}_{4}$ interface is equally "strong" as the LSM layer.

The LSM/OE interface had the lowest fracture energy among the tested interfaces $\left(0.1 \mathrm{~J} \mathrm{~m}^{-2}\right)$. A SEM image of the sample cross section after assembly (Fig. 5e) shows that the interface is well-defined, i.e. there was no significant interlocking/diffusion between the two layers as a result of the applied load and temperature $\left(28 \mathrm{~N} / \mathrm{cm}^{2}\right.$, $900{ }^{\circ} \mathrm{C}$ ). The $\sim 1.3 \mu \mathrm{m}$ wide transition zone indicated by the EDS linescan is close to the expected diameter of the interaction volume due to the electron beam penetration and spreading and is therefore not significant. The fracture surface (Fig. 5f) shows that the fracture was almost exclusively along the LSM/OE interface. The interface is weak as there was little mechanical interlocking and hardly any interdiffusion at this interface. 

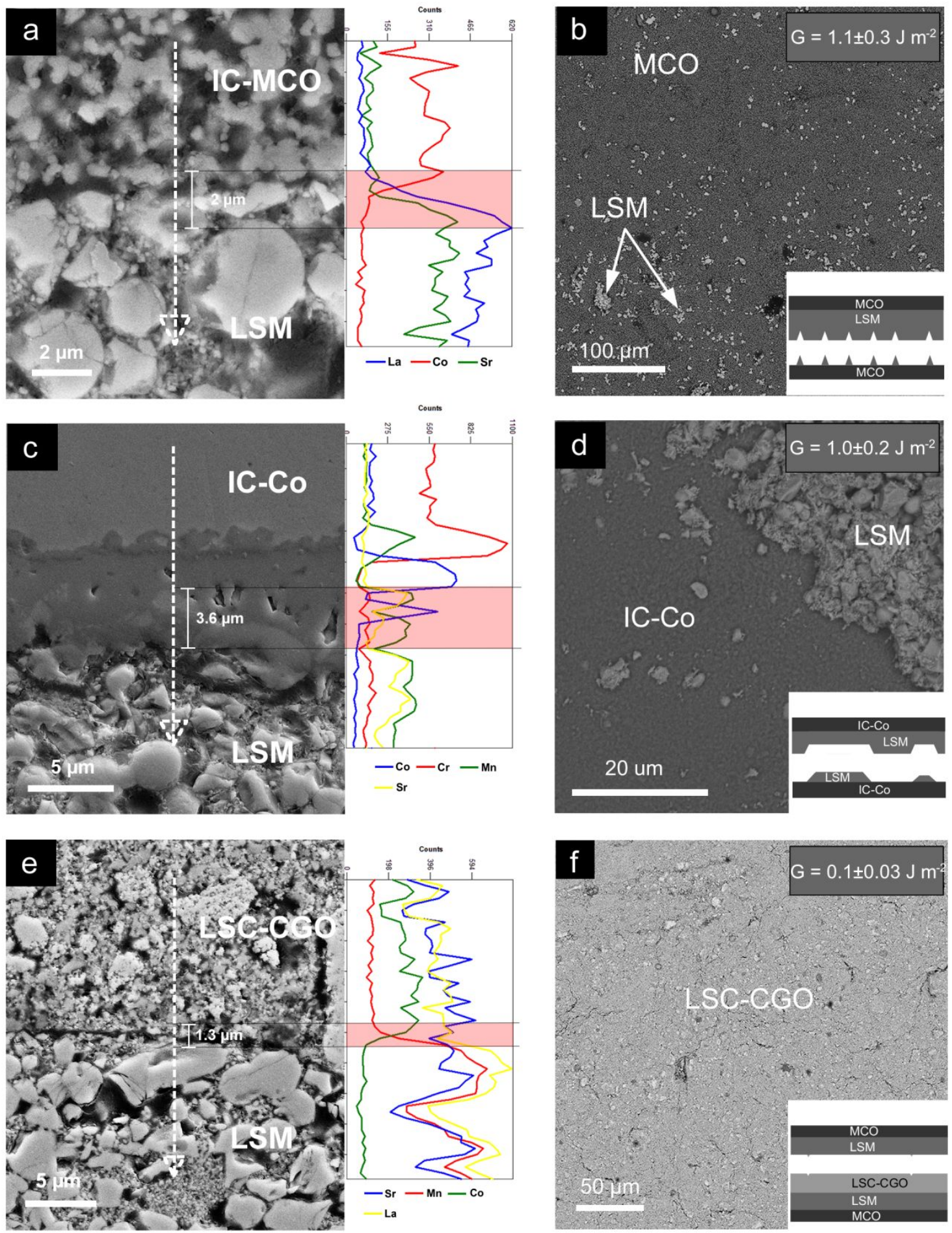

Fig. 5 SEM images of contact interfaces for (a) LSM/IC-MCO before fracture, (b) LSM/ IC-MCO after fracture, (c) LSM/ICCo before fracture, (d) LSM/ IC-Co after fracture, (e) LSM/OE before fracture, (f) LSM/OE after fracture. 


\subsubsection{LSC-LSM interfaces}

Using a mixture of LSM and LSC as the contact layer resulted in fracture energies intermediate of those obtained with the pure LSM and LSC contact layers. The cross section of the LSC-LSM/IC-MCO interface after assembly (Fig. 6a) indicates minimal interdiffusion between the two layers and the fracture surface (Fig. 6b) shows that the crack propagated almost exclusively along the $\mathrm{CL} / \mathrm{MCO}$ interface.

The cross section of the LSC-LSM/OE sample after assembly (Fig. 6c) indicates slightly greater interdiffusion and interlocking in than for the LSC-LSM/IC-MCO sample. Nevertheless, the resulting interface is weaker than in the case of the pure LSC contact layer. The fracture surface (Fig. 6d) is very smooth and indicates a fracture along the $\mathrm{CL} / \mathrm{OE}$ interface.
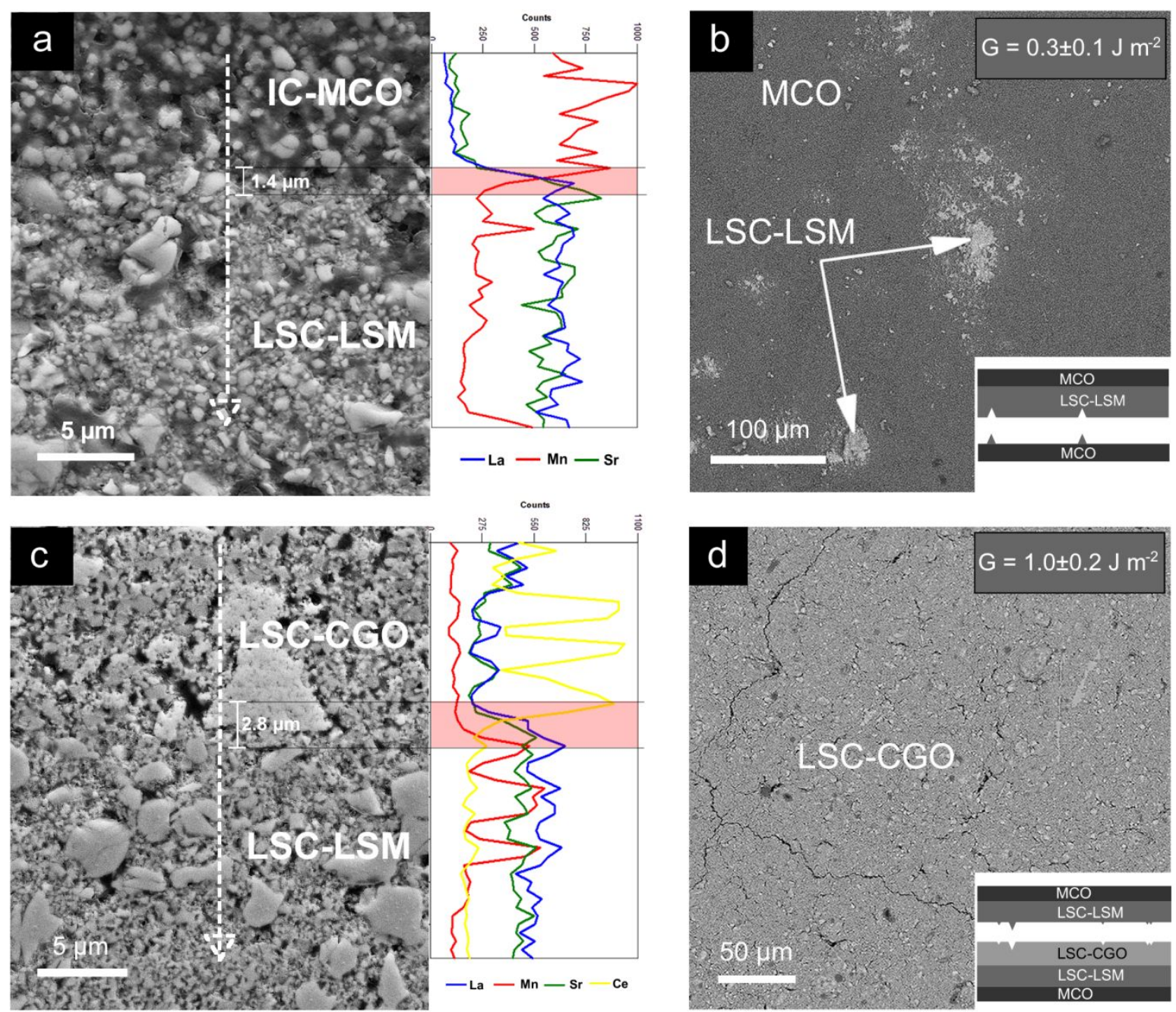

Fig. 6 SEM images of contact interfaces for (a) LSC-LSM/IC-MCO before fracture, (b) LSC-LSM/IC-MCO after fracture, (c) LSC-LSM/OE before fracture, (d) LSC-LSM/OE after fracture. 


\subsubsection{LNF interfaces}

The LNF contact layer resulted in the largest fracture energy values among the tested perovskite oxide contact layers. SEM images of the LNF contact layer (Fig. 7) show that the LNF particles are much finer $(\sim \varnothing 100 \mathrm{~nm})$ compared to the LSC and LSM particles in the contact layers previously discussed. Both interdiffusion and mechanical interlocking is enhanced, likely due to the higher sintering activity of the finer particles.

A SEM image and EDS linescan of the LNF/IC-MCO interface after assembly (Fig. 7a) shows a $\sim 2.9 \mu$ m wide transition zone of $\mathrm{Ni}, \mathrm{Mn}, \mathrm{Co}$, and $\mathrm{La}$. This transition zone is likely created by a combination of interdiffusion between the two layers and that the fine LNF particles were pressed into the pores of the MCO coating during assembly. The width of the transition zone is comparable to the width of the transition zone measured across the LSC/IC-MCO interface (Cf. Fig. 4a). The corresponding fractured surface of the LNF/IC-MCO sample (Fig. 7b) shows that large LNF clusters were pulled off and remained on the IC-MCO side after the fracture. I.e. the crack propagation took place both within the LNF layer and along the LNF/MCO interface, as illustrated in the drawing in the inset of Fig. 7b. This indicates that the CL/MCO interface is equally strong as the contact layer itself.

Similar observations are made for the LNF/IC-Co interface, i.e. the fracture takes place both within the LNF layer and at the $\mathrm{LNF} / \mathrm{Co}_{3} \mathrm{O}_{4}$ interface, as illustrated in Fig. 7d. Fig. 7c shows that the interdiffusion zone between $\mathrm{Co}_{3} \mathrm{O}_{4}$ and LNF is wider $(\sim 3.6 \mu \mathrm{m})$ than in the case of the MCO coating, likely as a result of LNF particles being incorporated into the coating when it is oxidized from Co to $\mathrm{Co}_{3} \mathrm{O}_{4}$. This results in a slightly better interface bonding.

The LNF/OE interface shows notable inter-diffusion between Fe/Ni (from LNF) and $\mathrm{Sr} / \mathrm{Co}$ (from LSC) as seen in the SEM-EDS line scan in Fig. 7e. As a result of the finer particle size, the LNF layer has adapted to the surface profile of the LSC-CGO oxygen electrode. This and the stronger reactivity (indicated by the more pronounced interdiffusion) has resulted in improved mechanical adhesion along the interface, which is reflected by a higher fracture energy $\left(1.4 \pm 0.3 \mathrm{~J} / \mathrm{m}^{2}\right)$. Inspections of the fractured surface (Fig. $7 \mathrm{f}$ ) show that the crack propagated through all the layers of the sample, indicating that the LNF/LSC-CGO interface is as strong as the surrounding layers, and hence serves its function at this interface. 

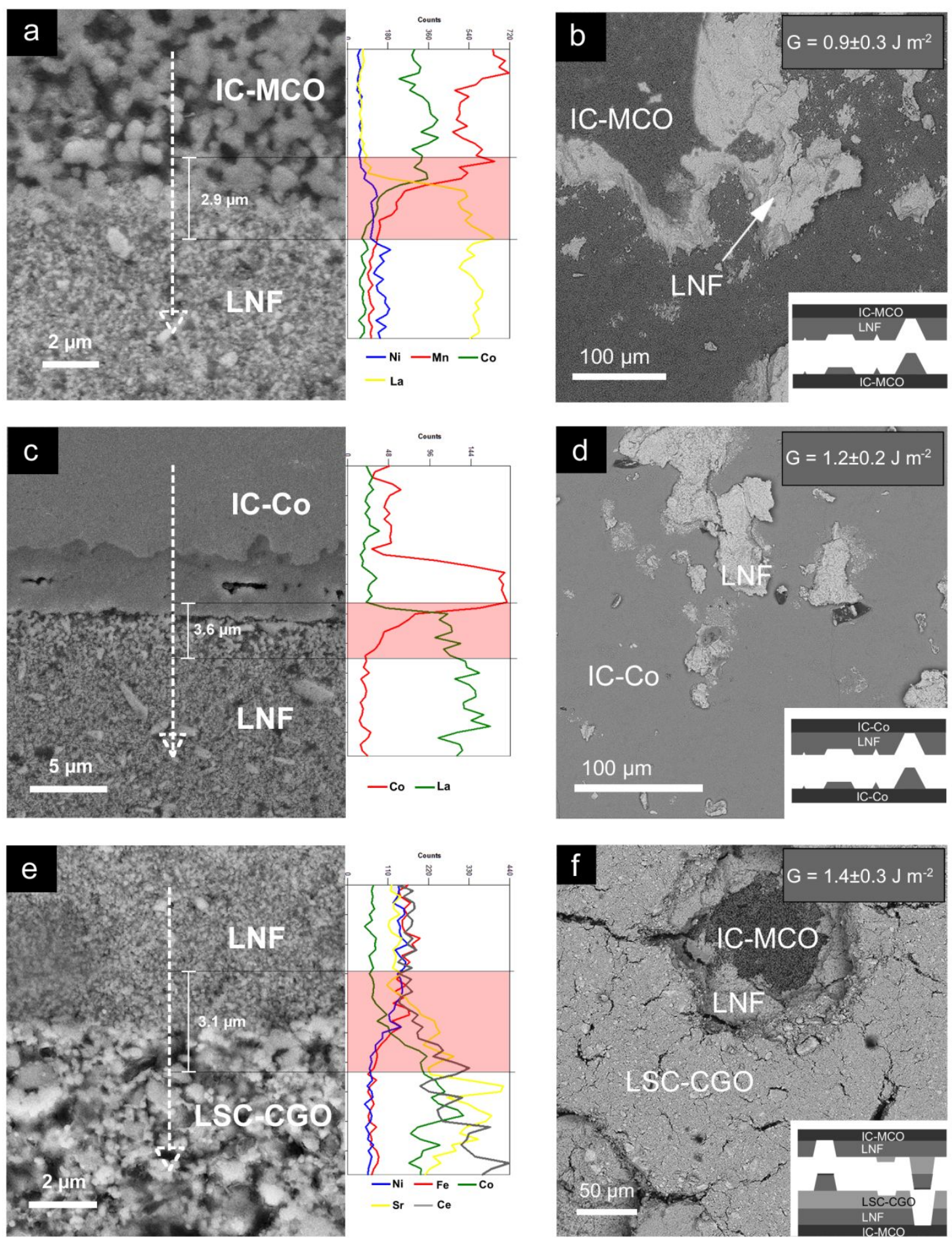

Fig. 7 SEM images of contact interfaces for (a) LNF/IC-MCO before fracture, (b) LNF/ IC-MCO after fracture, (c) LNF/ICCo before fracture, (d) LNF/ IC-Co after fracture, (e) LNF/OE before fracture, (f) LNF/OE after fracture. 


\subsubsection{CuMn foam interfaces}

The overall highest fracture energies were measured with CuMn foam as the contact layer. Especially the CL/MCO interface is greatly improved, being $\sim 8$ times higher $\left(8.6 \pm 1.2 \mathrm{~J} / \mathrm{m}^{2}\right)$ with CuMn than with any of the perovskite oxide contact layers. A SEM image of the CuMn contact layer sandwiched between two IC-MCO substrates is shown in Fig. 8a. As a result of the heat treatment in air at $900{ }^{\circ} \mathrm{C}$, the initially metallic CuMn foam was completely oxidized. EDS analysis indicated the presence of two main phases, a $\mathrm{Cu}$-rich oxide and a $\mathrm{Mn}+\mathrm{Cu}$-rich oxide, which most likely are the $\mathrm{CuO}$ and $(\mathrm{Mn}, \mathrm{Cu})_{3} \mathrm{O}_{4}$ phases reported in previous investigations of this $\mathrm{CuMn}$ foam [25]. The pressure applied during assembly $\left(28 \mathrm{~N} / \mathrm{cm}^{2}\right)$ resulted in some compression of the foam. Nevertheless, the foam remains highly porous on a macroscopic scale.

The originally porous MCO coating has been densified in areas where there is contact with the foam. This can be attributed to the interdiffusion between $\mathrm{Mn} / \mathrm{Cu}$ from the foam and $\mathrm{Co} / \mathrm{Mn}$ from the $\mathrm{MCO}$ coating. The EDS line scan across the densified part of the MCO coating (Line 1 in Figure $8 \mathrm{~b}$ ) shows that $\mathrm{Cu}$ has diffused all the way to the $\mathrm{Cr}_{2} \mathrm{O}_{3}$ scale on the steel. An EDS line scan across the MCO coating where it is not in contact with the CuMn foam (Line 2 in Figure 8b) shows no $\mathrm{Cu}$ in this area. Another difference between the dense and porous areas of the coating is the concentration of $\mathrm{Cr}$, which is much higher in the densified area. Inspections of the fracture surface (Fig. 8c) reveal that the breakage happened mostly within the foam, in proximity of the contact points with the MCO coating.

The CuMn foam/IC-Co interface showed a lower fracture energy $\left(2.7 \pm 0.4 \mathrm{~J} / \mathrm{m}^{2}\right)$ compared to the CuMn foam $/ \mathrm{IC}$ MCO interface $\left(8.6 \pm 1.2 \mathrm{~J} / \mathrm{m}^{2}\right)$. SEM-EDS elemental map of the CuMn foam/IC-Co interface after assembly (Fig. $8 \mathrm{~d}+\mathrm{e}$ ) shows that both $\mathrm{Cu}$ and $\mathrm{Mn}$ (from the contact layer) have inter-diffused with Co (from the coating) at the contact points. In addition, some $\mathrm{Cu}$, in the form of $\mathrm{CuO}$ according to $\mathrm{EDS}$, can be detected at the free surface of the coating, indicating high diffusivity of $\mathrm{Cu}$ on the surface of $\mathrm{Co}$ and/or $\mathrm{Co}_{3} \mathrm{O}_{4}$. In this case, there was no measurable difference in the concentration of $\mathrm{Cr}$ in the $\mathrm{Co}_{3} \mathrm{O}_{4}$ coating in the contact points relative to other parts of the coating, which is in contrast to what was observed for the CuMn foam/IC-MCO interface. SEM and EDS analysis of the fracture surface (Fig. 8f) shows a high concentration of $\mathrm{Cr}$ at points of fracture. This indicates that the weakest interface of the CuMn foam/IC-Co sample is near the $\mathrm{Cr}_{2} \mathrm{O}_{3}$ scale that has grown on the Crofer 22 APU surface during assembly $\left(10 \mathrm{~h}\right.$ at $\left.900{ }^{\circ} \mathrm{C}\right)$. That is, the fracture energy is a measure of the adhesion between the oxide scale and the steel, and the coating/contact layer interface is likely tougher.

The CL/OE interface had a nearly two times higher fracture energy with the CuMn foam compared to using the perovskite-based contact layers. A cross-sectional SEM image of the sample after assembly (Fig. 8g) shows that the foam has been compressed and deformed to coherently cover the surface of the LSC-CGO layer. An EDS linescan across the CuMn/LSC-CGO interface (Fig. 8h) shows some diffusion of $\mathrm{Cu}$ and Mn into the LSC-CGO layer. However, this diffusion was not as strong as in the case of the CuMn foam/IC-MCO interface, and there was no apparent densification of the oxygen electrode like observed for the MCO coating. A top-view SEM image of the fractured surface (Fig. 8i) shows that particles from the oxygen electrode were pulled off and remain on the foam. This suggest that the fracture mostly happened within the oxygen electrode, near the contact points with the foam (see the inset of Fig. 8i) and that the toughness of the oxygen electrode is limiting the fracture energy. 

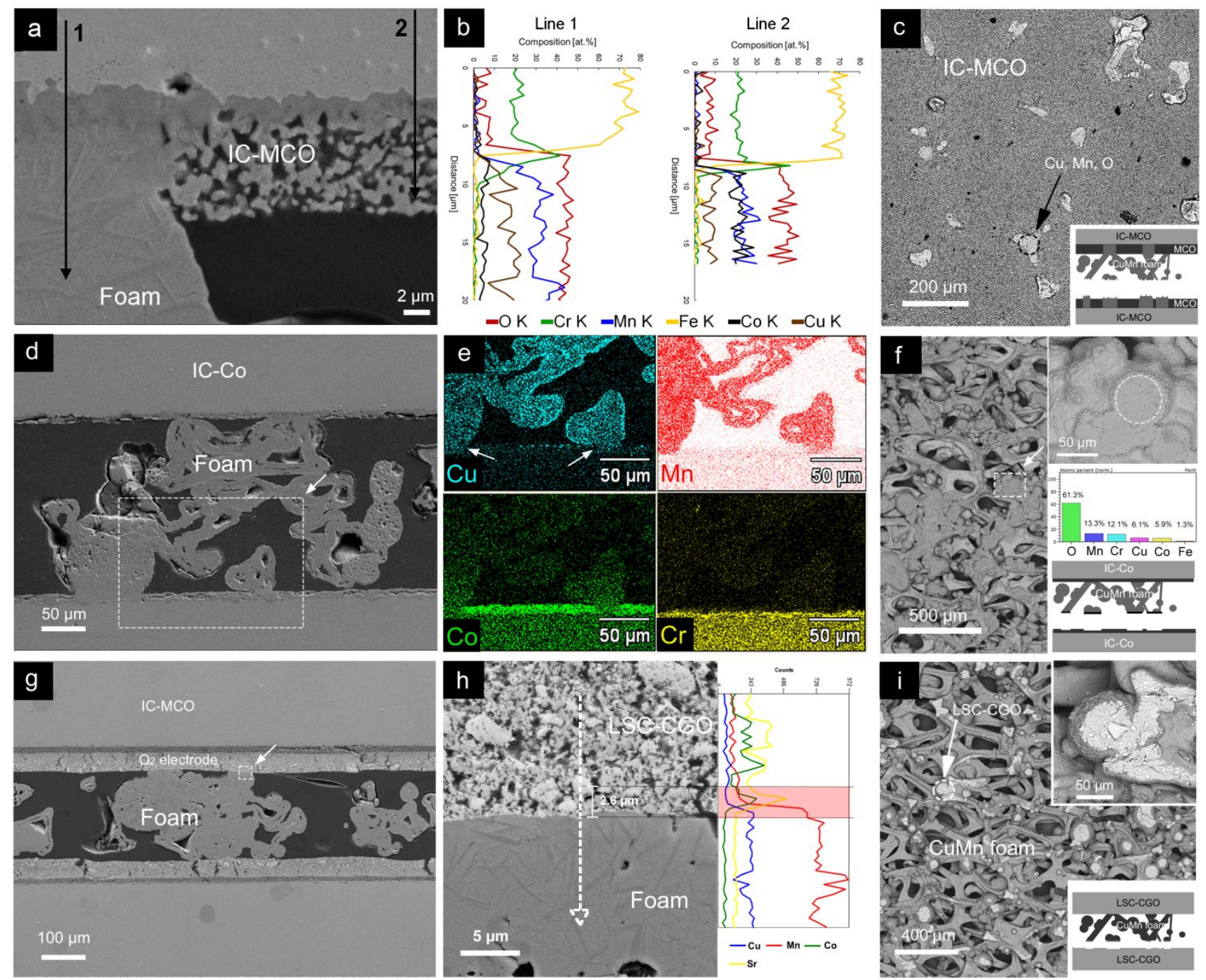

Fig. 8 (a) Cross-sectional SEM image of a CuMn foam/IC-MCO sandwich structure before fracture; (b) EDS linescans of the lines indicated in a; (c) top view of the IC-MCO side in a CuMn foam/IC-MCO interface after fracture; (d) Cross-sectional SEM image of a CuMn foam/IC-Co sandwich structure before fracture; (e) an SEM-EDS elementary mapping of the arrow pointed area in (d); (f) top view of the foam side in a CuMn foam/IC-Co interface after fracture; (g) Cross-sectional SEM image of a CuMn foam/OE sandwich structure before fracture; (h) a magnified image for the area in (g) pointed with an arrow; (i) top view of the foam side in a CuMn foam/OE interface after fracture.

\subsection{Discussion}

The fracture strength of the samples prepared with perovskite oxide contact layers was limited to ca. $1 \mathrm{~J} / \mathrm{m}^{2}$, which is consistent with the previously reported fracture strength of a LSM/IC-MCO interface $\left(1.7 \mathrm{~J} / \mathrm{cm}^{2}\right)$ using the same measurement method [35]. The low fracture strength can be attributed to the very limited sintering of the perovskite oxides at the assembly temperature of $900{ }^{\circ} \mathrm{C}$ [29]. Higher fracture energies may be achieved by sintering at a 
higher temperature, but the use of a higher temperature during stack assembly is generally undesired, due to thermal degradation of other stack components such as the steel interconnect and glass(-ceramic) sealant [46]. As an alternative approach to increasing the temperature, Tucker et al. [35] showed that the bonding between a LSM contact layer and MCO coated steel could be improved by the addition of glasses or an inorganic binder. The highest fracture energy $\left(12 \mathrm{~J} / \mathrm{cm}^{2}\right)$ was measured for a LSM-Schott glass composite contact layer sintered at 1000 ${ }^{\circ} \mathrm{C}$. However, testing of anode-supported button cells with LSCF cathodes and the LSM-Schott glass as the contact between the cell and a MCO coated 441 steel mesh current collector showed that this approach resulted in a high $(20 \% / 1000 \mathrm{~h})$ cell degradation rate.

Here, we have shown that by using CuMn foam as the contact material, the fracture energy of the CL/IC-MCO interface is increased by a factor of eight $\left(8.6 \mathrm{~J} / \mathrm{cm}^{2}\right)$ relative to the strongest perovskite oxide contact layer (LNF). The CuMn foam also improves the fracture energy of the CL/OE interface, but only by a factor of two $\left(2.7 \mathrm{~J} / \mathrm{cm}^{2}\right)$ relative to the strongest perovskite oxide. The much lower fracture energy of the $\mathrm{CuMn} / \mathrm{OE}$ interface relative to the CuMn/IC-MCO interface can be attributed to the poor toughness of the LSC-CGO oxygen electrode. The LSCCGO was sintered at a relatively modest temperature of $900{ }^{\circ} \mathrm{C}$ to protect the underlying steel substrate, while in normal SOC fabrication the oxygen electrode is typically sintered at temperatures $>1000{ }^{\circ} \mathrm{C}[46]$. As a higher sintering temperature will result in more necking between the LSC/CGO particles the fracture toughness will be higher.

The CuMn foam has shown promising results also in electrochemical tests. Zielke et al. [25] used CuMn foam as the contact layer between an anode-supported SOFC with a LSC-CGO cathode and a MCO coated interconnect/current collector. They reported an initial series resistance comparable to that of a cell tested using gold as the contact material, and moderate degradation rates during continuous SOFC operation.

In the following, the variations in the measured fraction energies for the tested interfaces will be explained on the basis of two bonding mechanism: 1) mechanical interlocking, and 2) reaction assisted bonding.

\subsubsection{Mechanical interlocking}

The load $\left(28 \mathrm{~N} / \mathrm{cm}^{2}\right)$ applied during the sample assembly forces the adjoining surfaces into close contact, which may, depending on the surface characteristics, result in a mechanical interlocking between the two layers. The significance of mechanical interlocking is demonstrated by the work of Chou et al. [47], who showed that the contact strength with a screen printed LSM contact layer could be improved up to a factor of 14 by engineering the surface. Mechanical interlocking is more easily established when the adjoining surfaces have a finer microstructure, as this translates to a larger surface area for contacting. Among the tested perovskite contact layers in this work, the LNF contact layer had the smallest particle size, followed by LSC, while LSM has the largest particle size. This is reflected in the measured fracture energy, which decreased in the order LNF $>$ LSC $>$ LSCLSM > LSM.

For the metallic layers (Co-coating and CuMn foam), mechanical interlocking is further enabled by the ability of the metal to deform under load and, more importantly, by the in-situ oxidation whereby the metal can expand into the voids of the adjacent layers. The result of these two effects is clearly seen from the cross sectional SEM images of the CL/IC-Co interfaces, showing that the contact layer particles are embedded in the oxidized Co coating (see for example Fig. 5c). As a consequence of the enhanced mechanical interlocking, the fracture energy was generally higher for the CL/IC-Co samples than for the CL/IC-MCO samples. The exception to this is when CuMn foam was used as the contact layer, where a three times higher fracture energy was measured for the CuMn/IC-MCO sample. This is because the Co-coating and the CuMn foam surface are both dense and relatively flat to begin with, making it more difficult to create mechanical interlocking, while the foam can more easily be pressed into the initially porous structure of the MCO coating. 


\subsubsection{Reaction assisted bonding}

Reaction between elements at the interfaces creates a chemical bonding, which improves the adhesion. Even though the formation of a reaction product at the interface is not observed, the observation of element interdiffusion is evidence that the arrangement (e.g. cation-anion distances) locally at the interface is co close to the one in the materials themselves that the cations can, by diffusion, shift from layer to layer. This means that there locally is some ionic bonding at the interface and that there is a solubility of the cations in one layer in the phase of the adjacent one. For the cases here, interdiffusion is primarily entropy-driven and extent of the interdiffusion depends on a number of factors, in particular the defect chemistry of the oxides and the chemical compatibility between the materials in the adjoining surfaces. An elaborate discussion of these factors is out of scope of the present work. Instead, we will focus on some of the trends observe in the results.

The width of the interdiffusion zones formed with the perovskite oxide contact layers was generally narrow $(<$ $3 \mu \mathrm{m})$. Among the tested perovskite oxides, LNF showed the overall highest reaction at all interfaces, while LSM showed the overall lowest extent of reaction. This can in part be attributed to the difference in size of the ceramic particles (LNF < LSM). Smaller particles generally have a relatively larger surface area and therefore greater driving force for reaction/sintering. Another factor is the stability of the contact layer material. In case of the LSC/IC-MCO sample, EDS analysis (Fig. 4a) indicated that Sr diffused further into the MCO coating compared to La. This is consistent with studies of LSC as the oxygen electrode material showing that $\mathrm{Sr}$ tends to segregate to the surface of LSC during operation $[48,49]$. The surface segregation of $\mathrm{Sr}$ is undesired when LSC is used as the oxygen electrode but may actually be an advantage for application as the contact layer, as the lower stability enhances reaction assisted bonding.

The CuMn foam represents a special case among the tested material, as the foam undergoes a transition from a metallic CuMn alloy to a ceramic oxide during the assembly process. In general, the Gibbs energy of oxide formation is several orders of magnitude larger than the Gibbs energy of surface reduction [50]. This enables densification of the contact layer at a much lower temperature compared to that needed to sinter the perovskite oxides.

The reaction and interdiffusion between the CuMn foam and the MCO coating is particularly strong. After the relatively short heat treatment $\left(10 \mathrm{~h}\right.$ at $\left.900{ }^{\circ} \mathrm{C}\right), \mathrm{Cu}$ from the $\mathrm{CuMn}$ foam was found at the original coating/oxide scale interface, corresponding to a diffusion distance of $\sim 10 \mu \mathrm{m}$. In addition to creating a very strong bond, the incorporation of $\mathrm{Cu}$ in the $(\mathrm{Mn}, \mathrm{Co})_{3} \mathrm{O}_{4}$ spinel has the benefit of increasing the electrical conductivity [45]. However, in areas of the coating where $\mathrm{Cu}$ had diffused, there was also a higher concentration of $\mathrm{Cr}$, which had diffused outward from the alloy. With time, the outward diffusion of $\mathrm{Cr}$ may deteriorate the electrical conductivity and fracture energy of the interface. Based on ASR measurements with a similar contact layer material, made by screen-printing a paste with $\mathrm{Cu}$ and $\mathrm{Mn}$ metal particles, the outward diffusion of $\mathrm{Cr}$ is not expected to have a negative influence on the electrical properties [51]. Nevertheless, we are currently investigating the effect of aging on the ASR and fracture energy of the CuMn foam/MCO-IC interface and will report the results elsewhere.

In summary, the high fracture energies achieved with the CuMn foam can be explained by: 1) the high deformability of the foam in its metallic state, enabling it to accommodate manufacturing tolerances and achieve a larger contact area to the adjoining surface; 2) the in-situ oxidation and associated volume expansion, during which the foam can expand into the porous structure of the adjoining surface, thereby creating a mechanical interlocking; and finally; 3 ) the reactivity between the oxidized foam and the adjoining surface, forming chemical bonds. 
Based on the findings in this work, several routes for further improvement of the contact strength and fracture toughness can be identified: 1) assembly/sintering at higher temperature, but as already mentioned, this may be unfeasible due to limited thermal stability of the other stack components; 2) use smaller oxide particles with higher sintering activity; 3) use more unstable compounds to promote reaction assisted bonding; and finally 4) use materials or sintering aids that form a transient liquid at modest assembly temperatures.

\section{Conclusions}

Five different types of contact layers, LSM, LSC, LSM-LSC, LNF, and CuMn foam, were evaluated based on their mechanical adhesion to both coated interconnects and a typical oxygen electrode material. The perovskite oxide contact layers showed facture energy values between $0.65 \mathrm{~J} / \mathrm{m}^{2}$ and $1.35 \mathrm{~J} / \mathrm{m}^{2}$ after assembly and heat treatment $\left(10 \mathrm{~h}\right.$ at $\left.900^{\circ} \mathrm{C}, 28 \mathrm{~N} / \mathrm{cm}^{2}\right)$, with the overall highest fracture energies measured with $\mathrm{LNF}$ as the contact layer. The low fracture energies of the perovskite oxides are attributed to the modest assembly temperature, which results in poor sintering and limited bonding of adjacent layers.

The CuMn foam formed strong mechanical bonding to both the $\mathrm{MCO}$ and Co-coated interconnects as well as to the oxygen electrode. When joined with a MCO coated interconnect, a Co-coated interconnect, and a LSC-CGO oxygen electrode, the interface fracture energy was increased to $8.6 \mathrm{~J} / \mathrm{m}^{2}, 2.7 \mathrm{~J} / \mathrm{m}^{2}$ and $2.5 \mathrm{~J} / \mathrm{m}^{2}$, i.e. eight times, three times, and two times larger than the average found for the conventional perovskite based contact layers, respectively. When joined to the MCO coated interconnect, the failure occurred in the foam itself, whereas for the lower values the foam pulled off parts of the adjoining layers (oxygen electrode, Co coating). Thus, the contact layer is no longer the weak link, but rather the oxygen electrode and Co coating.

In summary, application of a CuMn foam strongly improves the mechanical stability of the interface between the interconnect and the oxygen electrode well beyond what is achievable with conventional perovskite oxide contact layers.

\section{Acknowledgement}

The authors acknowledge colleagues Lene Knudsen, Ebtisam Abdellahi, Kjeld Bøhm Andersen, Pernille Hedemark Nielsen, John Johnson, and Henrik Paulsen at the Department of Energy Conversion and Storage in Technical University of Denmark (DTU Energy) for their technical assistances. Furthermore, the authors would like to acknowledge the financial support from DTU energy and the project "Towards Solid Oxide Electrolysis Plants in 2020" (Energinet.dk project no. 2015-1-12276).

\section{References}

[1] C. Graves, S.D. Ebbesen, M. Mogensen, K.S. Lackner, Sustainable hydrocarbon fuels by recycling CO2 and $\mathrm{H} 2 \mathrm{O}$ with renewable or nuclear energy, Renewable and Sustainable Energy Reviews. 15 (2011) 1-23. https://doi.org/10.1016/j.rser.2010.07.014.

[2] S.D. Ebbesen, J. Høgh, K.A. Nielsen, J.U. Nielsen, M. Mogensen, Durable SOC stacks for production of hydrogen and synthesis gas by high temperature electrolysis, International Journal of Hydrogen Energy. 36 (2011) 7363-7373. https://doi.org/10.1016/j.ijhydene.2011.03.130.

[3] S.D. Ebbesen, J.B. Hansen, M. Mogensen, Biogas Upgrading Using SOEC with a Ni-ScYSZ Electrode, ECS Trans. 57 (2013) 3217-3227. https://doi.org/10.1149/05701.3217ecst.

[4] I. Ridjan, B.V. Mathiesen, D. Connolly, SOEC pathways for the production of synthetic fuels: The transport case, Department of Development and Planning, Aalborg University, 2013. 
https://vbn.aau.dk/en/publications/soec-pathways-for-the-production-of-synthetic-fuels-the-transport (accessed October 4, 2019).

[5] K. Hassmann, SOFC Power Plants, the Siemens-Westinghouse Approach, Fuel Cells. 1 (2001) $78-84$. https://doi.org/10.1002/1615-6854(200105)1:1<78::AID-FUCE78>3.0.CO;2-Q.

[6] T. Alston, K. Kendall, M. Palin, M. Prica, P. Windibank, A 1000-cell SOFC reactor for domestic cogeneration, Journal of Power Sources. 71 (1998) 271-274. https://doi.org/10.1016/S0378-7753(97)027560 .

[7] K. Fujita, T. Seyama, T. Sobue, Y. Matsuzaki, Development of Segmented-in-series-type Solid Oxide Fuel Cells for Residential Applications, Energy Procedia. 28 (2012) 153-161. https://doi.org/10.1016/j.egypro.2012.08.049.

[8] T. Yamamoto, K. Yasumoto, M. Yoshikawa, H. Morita, Y. Mugikura, Performance Evaluations for Long Term Durability and Reliability of Segment-In-Series Tubular Type SOFCs, ECS Trans. 57 (2013) 763-770. https://doi.org/10.1149/05701.0763ecst.

[9] M. Noponen, P. Torri, J. Göös, J. Puranen, H. Kaar, S. Pylypko, M. Roostar, E. Õunpuu, Elcogen - Next Generation Solid Oxide Cell and Stack Technology, ECS Trans. 91 (2019) 91-97. https://doi.org/10.1149/09101.0091ecst.

[10] C. Geipel, K. Hauptmeier, K. Herbrig, F. Mittmann, M. Münch, M. Pötschke, L. Reichel, T. Strohbach, T. Seidel, A. Surrey, C. Walter, Stack Development and Industrial Scale-Up, ECS Trans. 91 (2019) 123-132. https://doi.org/10.1149/09101.0123ecst.

[11] L. Blum, An Analysis of Contact Problems in Solid Oxide Fuel Cell Stacks Arising from Differences in Thermal Expansion Coefficients, Electrochimica Acta. 223 (2017) 100-108. https://doi.org/10.1016/j.electacta.2016.12.016.

[12] T.T. Molla, K. Kwok, H.L. Frandsen, Modeling the Mechanical Integrity of Generic Solid Oxide Cell Stack Designs Exposed to Long-term Operation, Fuel Cells. 19 (2019) 96-109. https://doi.org/10.1002/fuce.201800081.

[13] A. Nakajo, Z. Wuillemin, J. Van herle, D. Favrat, Simulation of thermal stresses in anode-supported solid oxide fuel cell stacks. Part I: Probability of failure of the cells, Journal of Power Sources. 193 (2009) 203215. https://doi.org/10.1016/j.jpowsour.2008.12.050.

[14] R.R. Mosbaek, J. Hjelm, R. Barfod, J. Høgh, P.V. Hendriksen, Electrochemical Characterization and Degradation Analysis of Large SOFC Stacks by Impedance Spectroscopy, Fuel Cells. 13 (2013) 605-611. https://doi.org/10.1002/fuce.201200175.

[15] T.T. Molla, K. Kwok, H.L. Frandsen, Efficient modeling of metallic interconnects for thermo-mechanical simulation of SOFC stacks: Homogenized behaviors and effect of contact, International Journal of Hydrogen Energy. 41 (2016) 6433-6444. https://doi.org/10.1016/j.ijhydene.2016.03.002.

[16] G. Anandakumar, N. Li, A. Verma, P. Singh, J.-H. Kim, Thermal stress and probability of failure analyses of functionally graded solid oxide fuel cells, Journal of Power Sources. 195 (2010) 6659-6670. https://doi.org/10.1016/j.jpowsour.2010.04.017.

[17] V.I. Sharma, B. Yildiz, Degradation Mechanism in La0.8Sr0.2CoO3 as Contact Layer on the Solid Oxide Electrolysis Cell Anode, J. Electrochem. Soc. 157 (2010) B441-B448. https://doi.org/10.1149/1.3288835.

[18] E. Konysheva, J. Laatsch, E. Wessel, F. Tietz, N. Christiansen, L. Singheiser, K. Hilpert, Influence of different perovskite interlayers on the electrical conductivity between $\mathrm{La} 0.65 \mathrm{Sr} 0.3 \mathrm{MnO} 3$ and $\mathrm{Fe} / \mathrm{Cr}$-based steels, Solid State Ionics. 177 (2006) 923-930. https://doi.org/10.1016/j.ssi.2006.01.046.

[19] R.N. Basu, F. Tietz, O. Teller, E. Wessel, H.P. Buchkremer, D. Stöver, LaNi0.6Fe0.4O3 as a cathode contact material for solid oxide fuel cells, J Solid State Electrochem. 7 (2003) 416-420. https://doi.org/10.1007/s10008-002-0330-3.

[20] P. Hjalmarsson, PhD thesis - Strontium and nickel substituted lanthanum cobaltite as cathode in Solid Oxide Fuel Cells, (n.d.) 173.

[21] F. Tietz, Thermal expansion of SOFC materials, Ionics. 5 (1999) 129-139. https://doi.org/10.1007/BF02375916. 
[22] C. Sun, R. Hui, J. Roller, Cathode materials for solid oxide fuel cells: a review, J Solid State Electrochem. 14 (2010) 1125-1144. https://doi.org/10.1007/s10008-009-0932-0.

[23] R. Chiba, F. Yoshimura, Y. Sakurai, An investigation of LaNi1-xFexO3 as a cathode material for solid oxide fuel cells, Solid State Ionics. 124 (1999) 281-288. https://doi.org/10.1016/S0167-2738(99)00222-2.

[24] X. Montero, F. Tietz, D. Stöver, M. Cassir, I. Villarreal, Comparative study of perovskites as cathode contact materials between an $\mathrm{La} 0.8 \mathrm{Sr} 0.2 \mathrm{FeO} 3$ cathode and a Crofer22APU interconnect in solid oxide fuel cells, Journal of Power Sources. 188 (2009) 148-155. https://doi.org/10.1016/j.jpowsour.2008.11.083.

[25] P. Zielke, A.C. Wulff, X. Sun, S.H. Jensen, R. Kiebach, H.L. Frandsen, P. Norby, A. Hagen, Investigation of a Spinel-forming Cu-Mn Foam as an Oxygen Electrode Contact Material in a Solid Oxide Cell Single Repeating Unit, Fuel Cells. 17 (2017) 730-734. https://doi.org/10.1002/fuce.201700005.

[26] I. Lee, M.Y. Park, H.-J. Kim, J.-H. Lee, J.-Y. Park, J. Hong, K.-I. Kim, M. Park, J.-Y. Yun, K.J. Yoon, HighTemperature Current Collection Enabled by the in Situ Phase Transformation of Cobalt-Nickel Foam for Solid Oxide Fuel Cells, ACS Appl. Mater. Interfaces. 9 (2017) 39407-39415. https://doi.org/10.1021/acsami.7b13116.

[27] P. Szabo, R. Costa, F. Han, B. Kim, I. Lee, Investigation of Advanced Cathode Contacting Solutions in SOFC, in: N. Brandon (Ed.), Proceedings 12th European SOFC \& SOE Forum, Luzern, Schweiz, 2016. http://www.efcf.com/poc (accessed August 15, 2017).

[28] A. Petric, H. Ling, Electrical Conductivity and Thermal Expansion of Spinels at Elevated Temperatures, Journal of the American Ceramic Society. 90 (2007) 1515-1520. https://doi.org/10.1111/j.15512916.2007.01522.x.

[29] M.C. Tucker, L. Cheng, L.C. DeJonghe, Selection of cathode contact materials for solid oxide fuel cells, Journal of Power Sources. 196 (2011) 8313-8322. https://doi.org/10.1016/j.jpowsour.2011.06.044.

[30] X.D. Wang, W.B. Guan, R. Yu, W. Liu, W.L. Pei, X.D. Zhou, Correlation of ohmic resistance and interfacial adhesion strength between cathode and electrolyte for solid oxide fuel cells, International Journal of Hydrogen Energy. 41 (2016) 22337-22343. https://doi.org/10.1016/j.ijhydene.2016.08.031.

[31] Z. Lu, G. Xia, J.D. Templeton, X. Li, Z. Nie, Z. Yang, J.W. Stevenson, Development of Ni1-xCoxO as the cathode/interconnect contact for solid oxide fuel cells, Electrochemistry Communications. 13 (2011) 642645. https://doi.org/10.1016/j.elecom.2011.03.034.

[32] D.N. Boccaccini, O. Sevecek, H.L. Frandsen, I. Dlouhy, S. Molin, M. Cannio, J. Hjelm, P.V. Hendriksen, Investigation of the bonding strength and bonding mechanisms of SOFCs interconnector-electrode interfaces, Materials Letters. 162 (2016) 250-253. https://doi.org/10.1016/j.matlet.2015.07.137.

[33] P.G. Charalambides, J. Lund, A.G. Evans, R.M. McMeeking, A Test Specimen for Determining the Fracture Resistance of Bimaterial Interfaces, J. Appl. Mech. 56 (1989) 77-82. https://doi.org/10.1115/1.3176069.

[34] I. Hofinger, M. Oechsner, H.-A. Bahr, M.V. Swain, Modified four-point bending specimen for determining the interface fracture energy for thin, brittle layers, International Journal of Fracture. 92 (1998) 213-220. https://doi.org/10.1023/A:1007530932726.

[35] M.C. Tucker, L.C. DeJonghe, V. García-Negrón, R. Trejo, E. Lara-Curzio, Mechanical and electrochemical performance of composite cathode contact materials for solid oxide fuel cells, Journal of Power Sources. 239 (2013) 315-320. https://doi.org/10.1016/j.jpowsour.2013.03.130.

[36] I. Ritucci, R. Kiebach, B. Talic, L. Han, P. Zielke, P.V. Hendriksen, H.L. Frandsen, Improving the interface adherence at sealings in solid oxide cell stacks, Journal of Materials Research. (2019) 1-12. https://doi.org/10.1557/jmr.2018.459.

[37] J. Malzbender, R.W. Steinbrech, L. Singheiser, Determination of the interfacial fracture energies of cathodes and glass ceramic sealants in a planar solid-oxide fuel cell design, Journal of Materials Research. 18 (2003) 929-934. https://doi.org/10.1557/JMR.2003.0127.

[38] S. Molin, P. Jasinski, L. Mikkelsen, W. Zhang, M. Chen, P.V. Hendriksen, Low temperature processed $\mathrm{MnCo}_{2} \mathrm{O}_{4}$ and $\mathrm{MnCo}_{1.8} \mathrm{Fe}_{0.2} \mathrm{O}_{4}$ as effective protective coatings for solid oxide fuel cell interconnects at $750{ }^{\circ} \mathrm{C}$, Journal of Power Sources. 336 (2016) 408-418. https://doi.org/10.1016/j.jpowsour.2016.11.011. 
[39] S. Molin, M. Chen, P.V. Hendriksen, Oxidation study of coated Crofer 22 APU steel in dry oxygen, Journal of Power Sources. 251 (2014) 488-495. https://doi.org/10.1016/j.jpowsour.2013.09.100.

[40] H.L. Frandsen, D.J. Curran, S. Rasmussen, P.V. Hendriksen, High throughput measurement of high temperature strength of ceramics in controlled atmosphere and its use on solid oxide fuel cell anode supports, Journal of Power Sources. 258 (2014) 195-203. https://doi.org/10.1016/j.jpowsour.2014.02.036.

[41] A.G. Evans, M.D. Drory, M.S. Hu, The cracking and decohesion of thin films, Journal of Materials Research. 3 (1988) 1043-1049. https://doi.org/10.1557/JMR.1988.1043.

[42] Thyssen Krupp, Crofer 22 APU Material Data Sheet No. 4046, (2010).

[43] J. Malzbender, T. Wakui, R.W. Steinbrech, Curvature of Planar Solid Oxide Fuel Cells during Sealing and Cooling of Stacks, Fuel Cells. 6 (2006) 123-129. https://doi.org/10.1002/fuce.200500109.

[44] Y. Liu, J.W. Fergus, C.D. Cruz, Electrical Properties, Cation Distributions, and Thermal Expansion of Manganese Cobalt Chromite Spinel Oxides, J. Am. Ceram. Soc. 96 (2013) 1841-1846. https://doi.org/10.1111/jace.12254.

[45] B. Talic, P.V. Hendriksen, K. Wiik, H.L. Lein, Thermal expansion and electrical conductivity of $\mathrm{Fe}$ and $\mathrm{Cu}$ doped MnCo2O4 spinel, Solid State Ionics. 326 (2018) 90-99. https://doi.org/10.1016/j.ssi.2018.09.018.

[46] J. Nielsen, P. Hjalmarsson, M.H. Hansen, P. Blennow, Effect of low temperature in-situ sintering on the impedance and the performance of intermediate temperature solid oxide fuel cell cathodes, Journal of Power Sources. 245 (2014) 418-428. https://doi.org/10.1016/j.jpowsour.2013.06.067.

[47] Y.-S. Chou, J.F. Bonnett, J.W. Stevenson, Novel Approach to Strengthening Ceramic Cathode Contact and Validation in a Generic Stack Test Fixture, ECS Trans. 78 (2017) 1713-1720. https://doi.org/10.1149/07801.1713ecst.

[48] M. Finsterbusch, A. Lussier, J.A. Schaefer, Y.U. Idzerda, Electrochemically driven cation segregation in the mixed conductor La0.6Sr0.4Co0.2Fe0.8O3- $\delta$, Solid State Ionics. 212 (2012) 77-80. https://doi.org/10.1016/j.ssi.2012.02.006.

[49] T.T. Fister, D.D. Fong, J.A. Eastman, P.M. Baldo, M.J. Highland, P.H. Fuoss, K.R. Balasubramaniam, J.C. Meador, P.A. Salvador, In situ characterization of strontium surface segregation in epitaxial $\mathrm{La} 0.7 \mathrm{Sr} 0.3 \mathrm{MnO} 3$ thin films as a function of oxygen partial pressure, Appl. Phys. Lett. 93 (2008) 151904. https://doi.org/10.1063/1.2987731.

[50] R.M. German, Sintering Theory and Practice, 1996. http://adsabs.harvard.edu/abs/1996stp..book.....G (accessed February 21, 2016).

[51] B. Talic, I. Ritucci, R. Kiebach, P.V. Hendriksen, H.L. Frandsen, Improved Robustness and Low Area Specific Resistance with Novel Contact Layers for the Solid Oxide Cell Air Electrode, ECS Trans. 91 (2019) 2225-2232. https://doi.org/10.1149/09101.2225ecst. 
For table of contents only

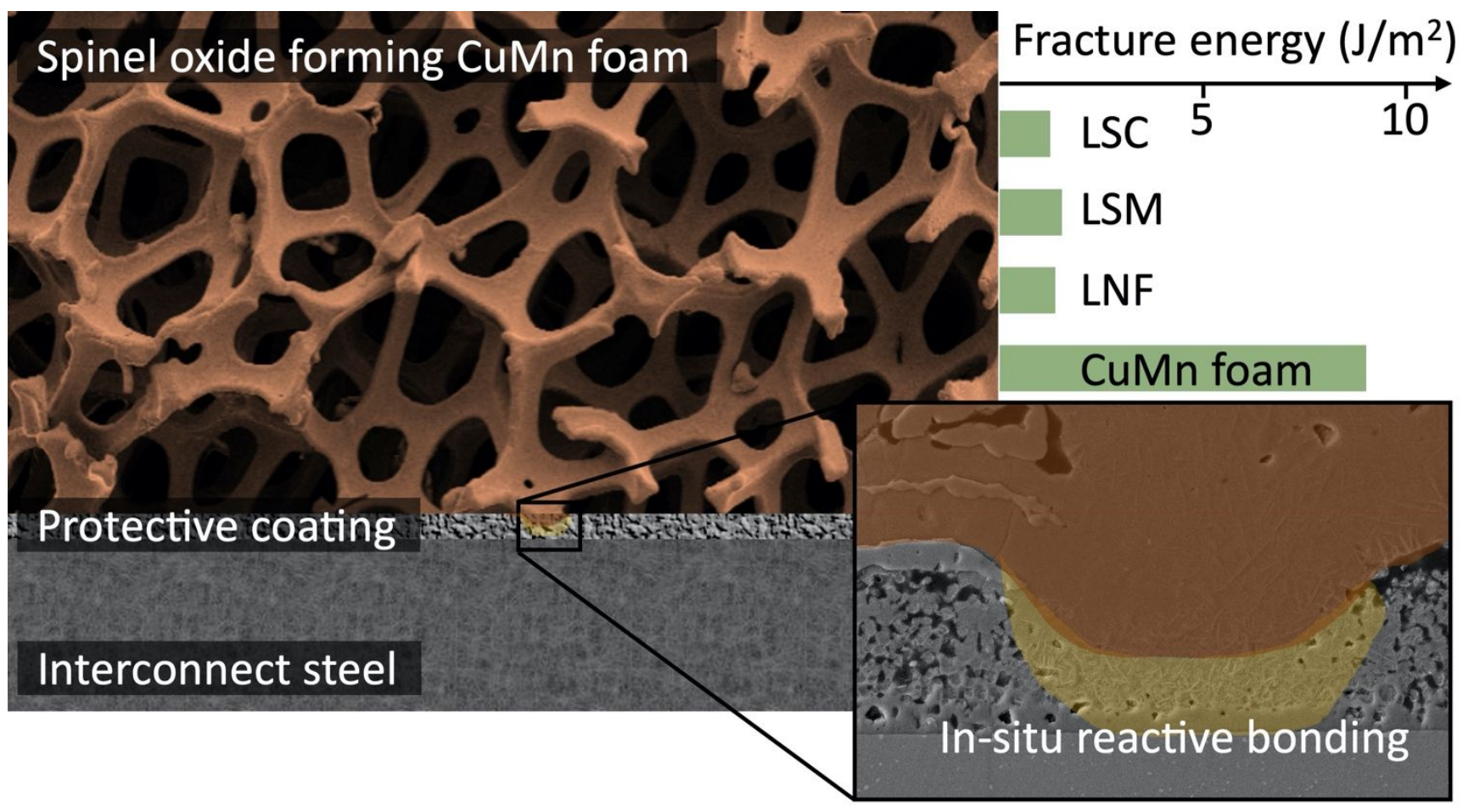

